\title{
Labor out-migration and agricultural change in rural China: A systematic review and meta-analysis
}

\author{
Hua Qin ${ }^{\text {a, }}$ and Tim F. Liao ${ }^{\mathrm{b}}$
}

\section{Acknowledgments}

We gratefully acknowledge the assistance of Xinyu Gao (a China Scholarship Council visiting student from the Department of Sociology at Hohai University, China) in searching for relevant Chinese publications for our systematic review. The cartography for Fig. 2 was done by Geography doctoral candidate $\mathrm{Li} \mathrm{Xu}$ at the University of Illinois at Urbana-Champaign. The work of Hua Qin in this research was partially supported by the USDA National Institute of Food and Agriculture, Hatch Projects \#1005128 and \#1005129. Tim Liao's research was in part supported by a sabbatical leave from the University of Illinois. Thoughtful comments on earlier versions of the article from Xinyu Gao, Elizabeth Prentice, three anonymous reviewers, as well as the special issue and journal editors are sincerely appreciated. 


\title{
Labor out-migration and agricultural change in rural China: A systematic review and meta-analysis
}

\begin{abstract}
The relationships between migration and agriculture represents a key aspect of rural restructuring in China and many other developing countries. Previous research largely generated mixed and incomplete findings on the effects of rural out-migration on agricultural change. Meta-analysis is considered as an important research strategy for comparing and integrating results from individual studies. Using a qualitative comparative analysis (QCA) approach, we conducted a systematic review and meta-analysis of recent case studies of labor out-migration and agricultural change in rural China. The analysis revealed general contextual patterns of migration impacts on agriculture. Migration-induced agricultural change was mainly conditional upon the specific conjunctural configuration of a rural community's economic development level or geographical locality, its land resources and dependence on agriculture, and whether the period under investigation was post-agricultural tax abolition. Overall, this meta-study provides the big picture of the complex migration-agriculture relationships in rural China, which is often missed in smaller-scale case studies. Such synthetic findings are particularly useful for informing evidence-based rural development planning and policy making.
\end{abstract}

Keywords: rural migration, agricultural restructuring, community context, qualitative comparative analysis, case studies 


\section{Introduction}

Rural areas across the world constantly experience social, economic and environmental transitions. Under the overarching processes of economic globalization and climate change, rural restructuring has become an important research topic linking multiple social science disciplines such as geography, sociology, anthropology, and planning (Woods, 2005). Although the existing literature on rural structural changes mainly focuses on developed countries, increasing research interests on similar issues in the developing world contexts have emerged in recent years (Long and Woods, 2011; Long, 2014; Woods, 2007). With the largest rural population among all nations and a rapidly growing market economy, China provides a particularly useful case for the study of restructuring processes and their consequences in rural areas.

Restructuring generally involves substantial changes in the conditions of, and the relationships between, constituent sectors of human society (Hoggart and Paniagua, 2001; Lovering, 1989). For both developed and developing countries, major dimensions of rural restructuring include (see Fig. 1): (1) shifts in agriculture and other economic activities (natural resource-based or not); (2) rural demographic dynamics (e.g., aging population and in- or outmigration); (3) altered sociocultural characteristics (e.g., traditions, perceptions, value systems, and community relations); and (4) changes in the rural environment including land use and land cover, soil quality, forest conservation, and rural pollution (Nelson, 2001; Wilson, 1995; Woods, 2005). Rural migration holds a key role in this framework since it is both an essential component of rural restructuring and a main driving force of changes in other dimensions. While contemporary rural restructuring in developed countries is characterized by urban-to-rural population flows (also known as turnaround migration or counterurbanization), much of the rural population mobility in the developing world involves seasonal labor migration from rural 
villages to urban centers. Rural labor migration and agricultural change are among the most widely studied aspects of rural restructuring in China and many other developing countries (Bernstein, 2015; Carr, 2009; Gray, 2009; Jokisch, 2002; Long et al., 2011; Qin, 2009, 2010; Zhang et al., 2015). However, previous research largely generated mixed and incomplete findings on the effects of rural out-migration on agricultural change.

The primary purpose of this study is to identify general patterns of migration impacts on agricultural production in rural China through a systematic review and meta-analysis of the recent literature. Meta-analysis has been increasingly used to integrate findings from individual case studies in environmental and natural resource social science (Qin and Grigsby, 2016; Robinson et al., 2014; Romero-Lankao et al., 2012; Rudel, 2008; Pagdee et al., 2006). Since the social and economic outcomes of migration in origin areas are highly contingent on local development contexts (de Haas, 2006; Durand and Massey, 1992), a case-oriented meta-analysis is particularly suitable for examining why the impacts of labor out-migration on agriculture are positive in some rural communities of China but negative in others. Such synthetic analysis can also provide a broader understanding of the complex migration-agriculture relationships in rural China, which is often missed in smaller-scale case studies.

The remainder of this article is organized as follows. The next section provides an overview of the existing literature on rural migration and agriculture in developing countries and particularly in China. Section 3 describes the detailed procedures of our systematic literature review and the meta-analytical method. After presenting the results of the meta-analysis in Section 4, we conclude with interpretations of major findings and some implications for future migration and rural restructuring research. 


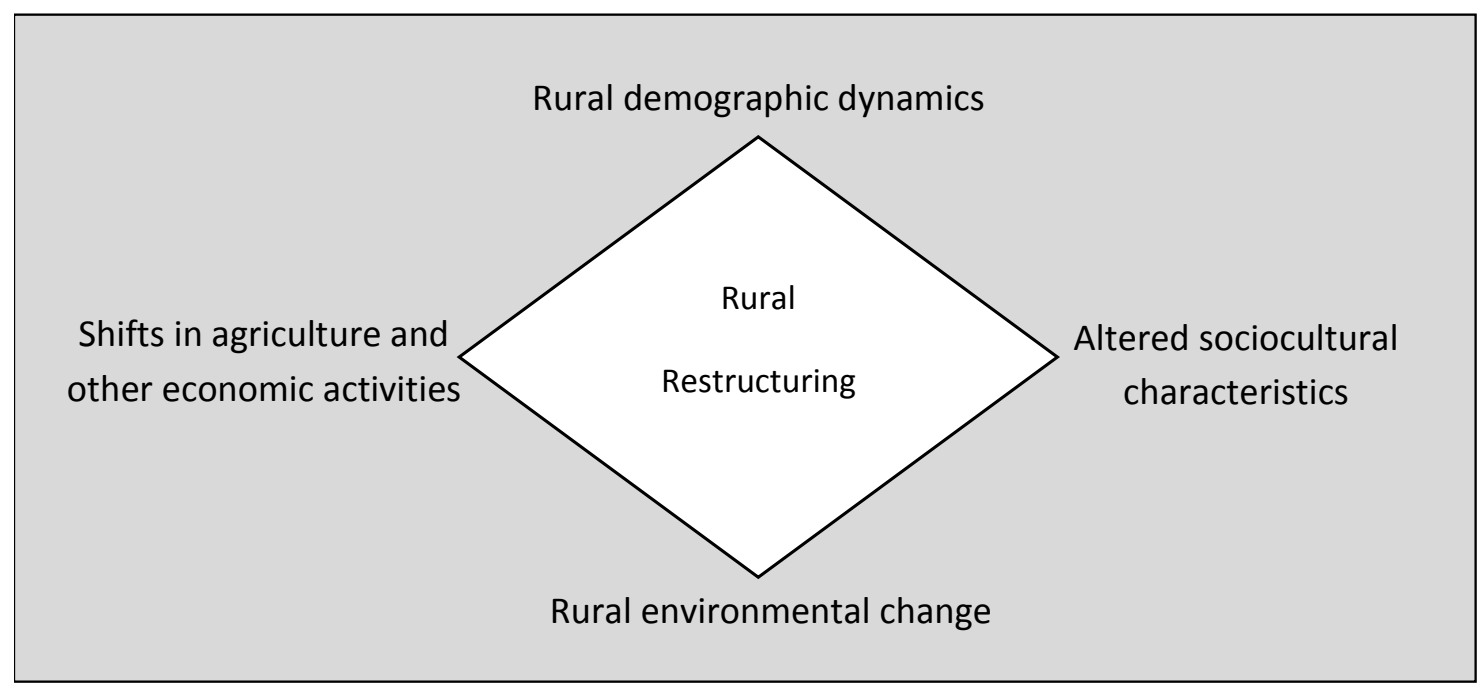

Fig. 1. A conceptual framework of rural restructuring. Source: Adapted from Nelson (2001)

\section{Rural out-migration and agricultural change}

\subsection{Rural out-migration and agriculture in the developing world}

Both agricultural production and labor migration are important livelihood strategies in the rural areas of developing countries (Carney, 1998; Ellis, 2000; Scoones, 2009). Distinct views exist with regard to the impacts of migration and remittances on rural livelihood outcomes. In the traditional "dependence and underdevelopment" view, rural out-migration exacerbates social and economic inequalities and creates an ever increasing dependency on labor migration, thereby undermining local livelihoods and social structures (Lipton, 1980; Reichert, 1981). By contrast, the "new economics of labor migration" view contends that migration and concomitant remittances can improve rural livelihoods through loosening production constraints, diversifying income sources, and providing financial capital for investment (Stark, 1991; Taylor, 1999). Based on an extensive literature review on the relationship between migration and rural 
development, de Haan (1999) concluded that the effects of migration on rural livelihoods were context-dependent and no easy generalizations could be made.

In a similar vein, there is a long-standing debate on the effects of rural labor migration on agricultural change in migrant sending communities (Gray and Bilsborrow, 2014; Jokisch, 2002; Mazambani, 1990; Qin, 2010). A popular view is that rural out-migration leads to labor shortage and thus threatens agricultural production (Black, 1993; Collins, 1988; Zimmerer, 1993). For instance, case studies from Zimbabwe found labor migrant households had less average farm labor input and lower production efficiency than non-migrant households, and suggested that in general labor migration was detrimental to communal land agriculture (Mazambani, 1990). A more recent rural household survey in the southern Yucatán peninsular region of Mexico also found that labor migrant households cultivated significantly less farmland and were more likely to invest in pasture development on extant land than non-migrant households (Schmook and Radel, 2008).

Nevertheless, an alternative view on the migration impacts on agriculture contends that remittances generated from labor migration can compensate for the reduction in labor input and provide capital resources for agricultural improvement and land purchases (Durand et al., 1996; Stark, 1980; Taylor, 1999). Abundant empirical evidence from different regions has also been found to support this argument. In rural Albania, McCarthy et al. (2006) found that households with international labor migrants had smaller land area planted in staples, fewer agricultural labor hours, and lower crop diversification index than non-migrant households. However, the results also suggested that the loss of household agricultural labor was compensated by increased access to capital and overall migration led to improvements in both agricultural and total household incomes. Likewise, de Haas (2006) showed that international migration remittances 
enabled migrant households to invest more than other households in water pumps, farmland reclamation, and the hiring of agricultural labor in Southern Morocco, and thus contributed to increased agricultural production. Additionally, Hull (2007) found that migrant households with remittances in rural Northeast Thailand were more likely than non-migrant households and households with migrants but no remittance to engage in traditional rice cultivation because of their enhanced capabilities to hire paid farm labor.

In addition to the two polarized views discussed above, a "middle-path" finding from south-central Ecuador showed that small landholding agricultural systems were not disturbed by labor out-migration, nor were remittances invested in agricultural cultivation or farm expansion (Jokisch, 2002). No significant difference in agricultural productivity was found between migrant and non-migrant households, or between different categories of migrant households (i.e. international and domestic). Drawing on household survey data from the southern Ecuadorian Andes, Gray (2009) also suggested that migrant-sending households did not differ from nonmigrant-sending households regarding the area cultivated in subsistence crops. Follow-up field research in larger study areas in rural Ecuador actually indicated a positive association between out-migration and agricultural expansion in cultivated land (Gray and Bilsborrow, 2014).

Beyond agricultural cultivation and productivity, a number of studies examined the influence of migration on rural household agricultural technology use and produced similarly inconclusive results. Some researchers argued that the labor scarcity of migrant households resulted in the decay and abandonment of traditional labor-intensive agricultural practices (Garcia-Barrios and Garcia-Barrios, 1990; Gilles et al., 2013; Zimmerer, 1993). Temporary labor migration may also prevent the adoption of new agricultural technologies of rural households due to the absence of key labor members and the reduced importance of farming for household 
livelihoods. Black (1993) found that in Northern Portugal non-migrant households were more likely than migrant households to employ technological innovations such as mechanized farming and improved seeds. Labor out-migration also tended to have a negative effect on the investment in non-labor agricultural inputs (e.g., chemical fertilizers and farm equipment rental) in rural Zimbabwe and Albanian (Mazambani, 1990; Miluka et al., 2010).

In contrast, a more optimistic perspective on the impacts of labor migration to agricultural technologies asserts that migration contributes to technological improvement in rural areas through the investment of remittances in more modern technologies and the stimulation of new skills and knowledge introduced by migrants (Oberai and Bilsborrow, 1984). This argument is partially confirmed by empirical evidence from a case study of labor migration in rural southern Swaziland. Simelane (1995) found that present and return labor migrants were more likely than non-migrants to own agricultural tractors. Remittances from male migrant workers to South African mining areas were also used by women to hire tractors, thus compensating for the shortage of labor and increasing agricultural production. In addition, a household survey-based study in rural Bangladesh showed that households with international migrants were more likely than non-migrant households to use modern farming technologies to improve agricultural productivity, though households with temporary or permanent domestic migrants had lower propensity to adopt such techniques (Mendola, 2008). This finding is also consistent with the results of a recent case study of rural Ecuador which concluded that international migration led to increased fertilizer use, cattle ownership, and the hiring of wage labor among migrant households (Vasco, 2011).

\subsection{Rural out-migration and agriculture in China}


The economic reform and the transition from a planned to market economy initiated in China in the late 1970s loosened the constraints that earlier prevented rural residents from working and living in the cities. Large economic disparities between urban and rural areas and among regions have generated a huge wave of rural migration labor to urban areas, especially from less-developed inland provinces to more developed coastal regions. The large-scale ruralurban labor migration has brought forth profound social, economic, and environmental changes in rural China. Findings from previous research on the impacts of rural out-migration on agriculture in China echo the various pathways of migration-agriculture relationships identified in the broader literature. In Hebei and Liaoning Provinces, Rozelle et al. (1999) found that rural households with labor migrants had lower agricultural productivity than those without migratory workers. However, migrant remittances nearly offset the differences between labor migrant and non-migrant households in agricultural production, thus mitigating the potential negative influences of lost household labor (Taylor et al., 2003). Similarly, field data from Sichuan and Anhui Provinces showed that rural labor out-migration did not inevitably disrupt grain production, while the effects on agriculture were even positive for low-cash-income households (Bai, 2001).

Davin (1999) maintained that given the labor surplus and the shortage of farmland in rural China, labor migration was unlikely to lead to idle cultivatable land or dramatic declines in land productivity and agricultural outputs. Nevertheless, several recent regional rural surveys suggested a trend of withdrawal from agricultural production for migrant households (Li et al., 2012; Li et al., 2014; Qin, 2010). Prior studies on the impacts of out-migration on agricultural technological efficiency also presented varied and even contradictory results (Chen et al., 2009; Luo et al., 2015; Yang et al., 2014; Yue, 2014). 
Previous researchers have identified inconsistent spatial patterns of migration-agriculture connections in China. $\mathrm{Li}$ (2001) contended that the impacts of labor migration on agricultural outputs were moderated by local agricultural resource conditions and economic development levels of rural origin areas. A comparative analysis of eight villages in four provinces of China revealed that migration and remittances supplemented or subsidized agriculture in mid-income and richer regions, but substituted for agriculture in poor and remote areas (Croll and Huang, 1997). Yue (2014) also found labor migration increased farm productivity in more developed eastern and central China, while the opposite was true in western regions. In contrast, Bai (2001) suggested rural migration negatively affected agricultural production in those regions where financial capital was not constrained, but had overall positive influences on agriculture in places where cash incomes were limited. Moreover, de Brauw and Rozelle (2008) demonstrated that although out-migration had a strong positive effect on consumptive investment of rural households in richer areas, no significant relationship was found between migration and productive or consumptive investment in poor study villages.

The multiplicity of potential migration effects on agricultural change reflects that the ways by which labor out-migration influences agriculture are conditioned by the socioeconomic and environmental contexts in migrant sending areas. Migration may affect agriculture differently depending on a range of local community characteristics such as soil quality, landholding size, commodity price, suitability for commercial agriculture, and irrigation condition (Durand and Massey, 1992; Gray, 2009; Jokisch, 2002). Although the existing research on the migration impacts on agriculture in China focuses on the household unit of analysis and is mainly conducted at the regional or national scale, it also indicates the moderating roles of various community-level factors including local dependence on agriculture, natural 
environmental conditions (e.g., topography and land quality), availability of farmland,

profitability of farming, average annual income, and local off-farm work opportunities (Croll and Huang, 1999; Li and Tonts, 2014; Li et al., 2012; Li et al., 2013). Furthermore, since nearly all of the previous studies in this area used a cross-sectional approach, the temporal dimension of the relationship between rural migration and agricultural restructuring in China has been largely overlooked.

\section{Methods}

\subsection{A meta-analysis of case studies using qualitative comparative analysis}

This study adopts a meta-analysis of case studies approach to explore general patterns of local contextual effects on migration-induced agricultural change in rural China. Qualitative comparative analysis (QCA) provides a particularly useful technique to compare and synthesize results across relatively small collections of case studies of social and environmental changes (Rudel, 2008). This method originally required the construction of a dataset of binary variables indicating the presence or absence of some phenomena, and has been further developed with the inclusion of multi-value variables and fuzzy sets (Ragin, 2000; Vink and van Vliet, 2009). QCA draws on Boolean logic to reveal minimized combinations of conditions that are associated with particular outcomes (Ragin, 2014). Unlike typical multivariate statistical techniques, QCA stresses the conjoint relationships among influencing factors instead of their individual effects. The conjunctural configurations generated from the integrative, case-oriented QCA analysis can facilitate the development of empirical generalizations with respect to complex research problems. 


\subsection{Literature search}

We searched the title field of Google Scholar and the Social Sciences I and Economic \& Management Sciences databases of the Chinese National Knowledge Infrastructure (CNKI) using key word combinations including "migration/remittance(s)" AND “agriculture/agricultural/farming/livelihood(s)/(farm)land” AND "China/Chinese”, and "renkou liudong (population mobility)/renkou qianyi (migration)/chengxiang yimin (rural-urban migration)/laodongli zhuanyi (labor transfer)/laodongli liudong (labor mobility)" AND “nongye (agriculture)/shengji (livelihood)/tudi (land)/gengdi (farmland)", respectively (Chinese Pinyin texts in italics). ${ }^{1}$ We screened the titles and abstracts of the 375 records (95 from Google Scholar and 280 from $\mathrm{CNKI}$ ) retrieved through the initial search, while the reference lists of publications selected for full review were also crosschecked for additional relevant studies. A case in our meta-analysis is a specific study area or community where labor out-migration resulted in subsequent change in the agricultural sector. To be included in our systematic review, a study must include empirical, evidence-based conclusions about the impacts of labor migration on agriculture in a limited number of study sites as well as sufficient information about local socioeconomic and environmental characteristics. Large-scale survey research aggregating data from multiple provinces of China was thus excluded in the search process. When a study involved investigations of individual sites, each of them was considered as a separate case. Cases based on the same or similar field data from a study area were combined together. As a result, 20 case studies from 12 publications were eventually selected for the systematic review and meta-

\footnotetext{
${ }^{1}$ A single combination included one key word from each subset. The literature search was conducted in September 2015, and covered all publications available in Google Scholar and CNKI up to then.
} 
analysis (see Table 1). The study sites of these cases were located in 9 provinces and municipalities across different regions of China (see Fig. 2). 


\section{Table 1}

Case studies and associated publications included in the meta-analysis

\begin{tabular}{|c|c|c|c|}
\hline No. & Study site $^{\mathrm{a}}$ & Source & Case ID \\
\hline 1 & Village 1 in Jiangsu Province & Croll and Huang 1997 & CrollHuang97-01 \\
\hline 2 & Village 3 in Anhui Province & Croll and Huang 1997 & CrollHuang97-03 \\
\hline 3 & Village 4 in Anhui Province & Croll and Huang 1997 & CrollHuang97-04 \\
\hline 4 & Village 5 in Sichuan Province & Croll and Huang 1997 & CrollHuang97-05 \\
\hline 5 & Village 6 in Sichuan Province & Croll and Huang 1997 & CrollHuang97-06 \\
\hline 6 & Village 7 in Gansu Province & Croll and Huang 1997 & CrollHuang97-07 \\
\hline 7 & Village 8 in Gansu Province & Croll and Huang 1997 & CrollHuang97-08 \\
\hline 8 & $\begin{array}{l}\text { Two villages in Wanzai County, } \\
\text { Jiangxi Province }\end{array}$ & Murphy 2002 & Murphy02 \\
\hline 9 & $\begin{array}{l}\text { Shannangou Village in Yanqing } \\
\text { District, Beijing Municipality }\end{array}$ & Wei 2005 & Wei05-01 \\
\hline 10 & $\begin{array}{l}\text { Dayugou Village in Fangshan } \\
\text { District, Beijing Municipality }\end{array}$ & Wei 2005 & Wei05-02 \\
\hline 11 & $\begin{array}{l}\text { Haojiang Village in Jianghua } \\
\text { County, Hunan Province }\end{array}$ & Li 2006 & Li06-01 \\
\hline 12 & $\begin{array}{l}\text { Wucheng Village in Yongxing } \\
\text { County, Hunan Province }\end{array}$ & Li 2006 & Li06-02 \\
\hline 13 & $\begin{array}{l}\text { Bailin Village in Beibei District, } \\
\text { Chongqing Municipality }\end{array}$ & $\begin{array}{l}\text { Qin 2010; Qin and } \\
\text { Flint 2012a }\end{array}$ & Qin1012-01 \\
\hline 14 & $\begin{array}{l}\text { Banliao Village in Wansheng } \\
\text { District, Chongqing Municipality }\end{array}$ & $\begin{array}{l}\text { Qin 2010; Qin and } \\
\text { Flint 2012a }\end{array}$ & Qin1012-02 \\
\hline 15 & $\begin{array}{l}\text { Dacao Village in Kaixian District, } \\
\text { Chongqing Municipality }\end{array}$ & $\begin{array}{l}\text { Qin 2010; Qin and } \\
\text { Flint 2012a }\end{array}$ & Qin1012-03 \\
\hline 16 & $\begin{array}{l}\text { Tuanjie Village in Qianjiang } \\
\text { District, Chongqing Municipality }\end{array}$ & $\begin{array}{l}\text { Qin 2010; Qin and } \\
\text { Flint 2012a }\end{array}$ & Qin1012-04 \\
\hline 17 & $\begin{array}{l}\text { Four townships in Zhouzi County, } \\
\text { Shaanxi Province }\end{array}$ & $\begin{array}{l}\text { Li et al. 2010; Li et al. } \\
2012\end{array}$ & LiEtal1012 \\
\hline 18 & $\begin{array}{l}\text { Three villages in Qingyang } \\
\text { Prefecture, Gansu Province }\end{array}$ & $\begin{array}{l}\text { Li et al. } 2013 ; \mathrm{Li} \text { and } \\
\text { Tonts } 2014\end{array}$ & LiEtal1314 \\
\hline 19 & $\begin{array}{l}\text { Three townships in Pengshui } \\
\text { County, Chongqing Municipality }\end{array}$ & Liu 2014 & Liu14 \\
\hline 20 & $\begin{array}{l}\text { Three villages in Yudu County, } \\
\text { Jiangxi Province }\end{array}$ & Luo 2014 & Luo14 \\
\hline
\end{tabular}

\footnotetext{
${ }^{a}$ Village 2 in Croll and Huang (1997) and Ya'ai Village in Li (2006) were excluded from the analysis since labor migration in these two sites mainly took the form of local commuting which was substantially different from the more long-distance migration pattern found in all other cases.
} 


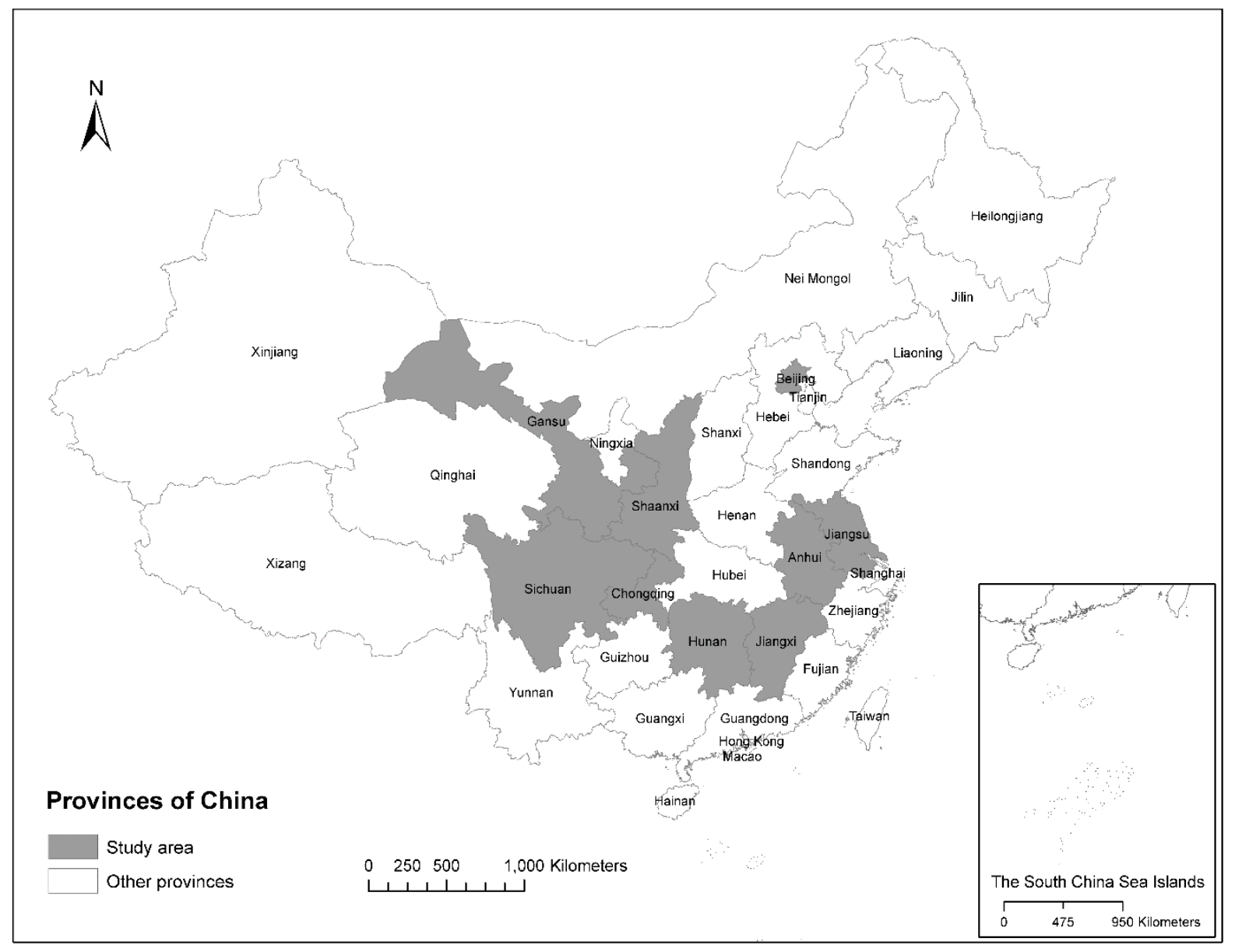

Fig. 2. Provinces and municipalities covered in the meta-analysis (cartography by Li Xu)

\subsection{Coding of case studies}

The coding of selected case studies followed a structured, iterative process. Previous studies have identified a range of socioeconomic and environmental contextual factors that may shape the impacts of rural out-migration on agricultural change (see Section 2.2). These findings informed the design of a preliminary manual for coding key contextual variables from the selected case studies. The initial identification guidelines were further refined during the systematic review process. Additionally, the time of study was also included in the final coding since we expected the relationship between out-migration and agriculture in China might be 
directly affected by its agricultural taxation reform which culminated in the nationwide elimination of agricultural taxes and fees in 2006 (Xu et al., 2012).

Table 2 presents detailed operationalization of all the constructed variables. Dichotomous observation was employed for determining the attributes of migration impacts on agriculture since QCA requires a binary outcome variable. This classification scheme was also applied to the coding of all other factors except for the magnitude of labor out-migration and geographical region. The determination of variable values for individual cases was mainly based on the qualitative and/or quantitative descriptions of study sites included in the selected studies. This process was also facilitated by comparison among cases in the pool or with national average levels in the coding of several variables such as the overall assessment of local natural conditions and the quantity of farmland. All of the 20 case studies were reviewed and coded by both coauthors to ensure consistent data extraction. 


\section{Table 2}

Definitions and possible values of variables in the meta-analysis

\begin{tabular}{|c|c|c|}
\hline Variable name & Definition & Possible values \\
\hline MigrationImpact & $\begin{array}{l}\text { Impacts of labor out-migration on } \\
\text { agriculture in a locality under study }\end{array}$ & $\begin{array}{l}0=\text { negative (e.g., migration resulted in } \\
\text { disinvestment in agriculture and/or farmland } \\
\text { abandonment) } 1=\text { positive (e.g., remittances } \\
\text { from labor migrants subsidized agriculture, } \\
\text { increased the scale of agricultural production, } \\
\text { and/or offset the negative effects of labor } \\
\text { migrants' absence) })^{\mathrm{a}}\end{array}$ \\
\hline LaborMigration & Magnitude of local labor migration & $\begin{array}{l}0=\text { relatively low (labor migrants accounted } \\
\text { for less than } 25 \% \text { of the total labor force), } 1= \\
\text { moderate (labor migrants accounted for } 25- \\
49 \% \text { of the total labor force), } 2=\text { high (labor } \\
\text { migrants accounted for } 50 \% \text { or more of the } \\
\text { total labor force) }\end{array}$ \\
\hline Region & $\begin{array}{l}\text { Geographical region in which a study site } \\
\text { was located }\end{array}$ & $\begin{array}{l}0=\text { east region, } 1=\text { central and northeast } \\
\text { region, } 2=\text { west region }^{\mathrm{b}}\end{array}$ \\
\hline Topography & Topographic characteristics of locality & $0=$ plain, $1=$ hilly or mountainous \\
\hline NaturalEndowments & $\begin{array}{l}\text { Overall assessment of local natural } \\
\text { conditions }\end{array}$ & $0=$ relatively poor, $1=$ moderate or rich \\
\hline LandResources & Quantity of farmland in locality & $0=$ relatively low, $1=$ moderate or high \\
\hline AgriDependence & Local dependence on agriculture & $0=$ relatively low, $1=$ moderate or high \\
\hline CashCrop & Profitable cash crop production in locality & $0=$ no, $1=$ yes \\
\hline EconDevelopment & Economic development level of locality & $0=$ relatively low, $1=$ moderate or high \\
\hline NonfarmWork & $\begin{array}{l}\text { Availability of local non-farm } \\
\text { employment opportunities }\end{array}$ & $0=$ little $/$ no, $1=$ yes \\
\hline StudyTime & Time when the study was conducted & $\begin{array}{l}0=\text { before the agricultural tax abolition in } \\
2006,1=\text { after the agricultural tax abolition in } \\
2006\end{array}$ \\
\hline
\end{tabular}

\footnotetext{
${ }^{a}$ The selected studies focused on different outcomes in their examination of the impacts of labor out-migration on agriculture. We used a general outcome variable in the analysis due to the small case number. Multiple outcome measures may be included if there are enough cases for specific dimensions of agricultural change. Separate QCA analyses can then be conducted for individual outcomes.

b The value "1" for "Region" refers only to Central China in this study since there is no case from the northeast region in our meta-analysis dataset.
} 


\subsection{Analytical procedures}

We used QCA in the analysis of the data inventory constructed through the systematic review and data extraction. The analysis first sorted different combinations of values on the contextual factors and their associated values on the outcome variable (the effects of outmigration on agriculture) into a truth table (see Table 3). The QCA technique then used Boolean algebra to convert the combinations of conditions in the truth table to reduced configurations (prime implicants). The presence and absence of a condition are respectively represented by uppercase and lowercase letters in Boolean statements. The Boolean approach includes two basic types of operations: Boolean addition $(\mathrm{A}+\mathrm{B} \rightarrow \mathrm{Y}$, which means either the presence of $\mathrm{A}$ or $\mathrm{B}$ can lead to the outcome $\mathrm{Y}$ ), and Boolean multiplication $(\mathrm{AB} \rightarrow \mathrm{Y}$, which means the presence of both A and B induces the outcome Y). The expression minimization in QCA follows straightforward Boolean logic and essential prime implicant selection procedures to generate parsimonious solutions. The most fundamental rule of Boolean reduction is: "if two Boolean expressions differ in only one causal condition yet produce the same outcome, then the causal condition that distinguishes the two expressions can be considered irrelevant and can be removed to create a simpler, combined expression" (Ragin, 2014, p. 93). The minimization process of this study was conducted with a multi-value QCA (MVQCA) software package - TOSMANA (Tool for Small-N Analysis) Version 1.3 since unlike the traditional QCA tool, it allows the inclusion of categorical variables with more than two possible values rather than just dichotomous data (Cronqvist, 2011; Vink and van Vliet, 2009). 


\section{Table 3}

Truth table for the QCA analysis ${ }^{\mathrm{a}}$

\begin{tabular}{|c|c|c|c|c|c|c|c|c|c|c|c|}
\hline \multicolumn{10}{|c|}{ Contextual factors $^{a}$} & \multirow{2}{*}{$\begin{array}{l}\text { Outcome } \\
\text { Migration } \\
\text { Impact }\end{array}$} & \multirow[b]{2}{*}{ Case IDs $^{b}$} \\
\hline $\begin{array}{l}\text { Labor } \\
\text { Migration }\end{array}$ & Region & $\begin{array}{l}\text { Topo- } \\
\text { graphy }\end{array}$ & $\begin{array}{l}\text { Natural } \\
\text { Endowments }\end{array}$ & $\begin{array}{l}\text { Land } \\
\text { Resources }\end{array}$ & $\begin{array}{l}\text { Agri } \\
\text { Dependence }\end{array}$ & $\begin{array}{l}\text { Cash } \\
\text { Crop }\end{array}$ & $\begin{array}{l}\text { Econ } \\
\text { Development }\end{array}$ & $\begin{array}{l}\text { Nonfarm } \\
\text { Work }\end{array}$ & $\begin{array}{l}\text { Study } \\
\text { Time }\end{array}$ & & \\
\hline 0 & 0 & 0 & 1 & 0 & 0 & 0 & 1 & 1 & 0 & 1 & CrollHuang97-01 \\
\hline 1 & 1 & 0 & 1 & 1 & 0 & 0 & 1 & 1 & 0 & 1 & CrollHuang97-03 \\
\hline 0 & 1 & 0 & 1 & 1 & 0 & 0 & 1 & 1 & 0 & 1 & CrollHuang97-04 \\
\hline 2 & 2 & 1 & 0 & 0 & 1 & 1 & 0 & 0 & 0 & 0 & CrollHuang97-05 \\
\hline 1 & 2 & 1 & 0 & 1 & 1 & 1 & 0 & 0 & 0 & 0 & CrollHuang97-06 \\
\hline 0 & 2 & 1 & 0 & 1 & 1 & 0 & 0 & 1 & 0 & 0 & CrollHuang97-07 \\
\hline 1 & 2 & 1 & 1 & 1 & 1 & 1 & 0 & 0 & 0 & 0 & CrollHuang97-08 \\
\hline 1 & 1 & 1 & 0 & 0 & 1 & 0 & 0 & 0 & 0 & 1 & Murphy02 \\
\hline 1 & 0 & 1 & 0 & 1 & 1 & 1 & 1 & 0 & 0 & 1 & Wei05-01 \\
\hline 2 & 0 & 1 & 0 & 0 & 1 & 1 & 1 & 0 & 0 & 1 & Wei05-02 \\
\hline 2 & 1 & 1 & 0 & 0 & 0 & 0 & 0 & 0 & 0 & 0 & Li06-01 \\
\hline 0 & 1 & 1 & 0 & 1 & 1 & 1 & 0 & 0 & 0 & 0 & Li06-02 \\
\hline 1 & 2 & 1 & 0 & 0 & 0 & 0 & 0 & 1 & 1 & 0 & Qin1012-01 \\
\hline 2 & 2 & 1 & 1 & 0 & 1 & 0 & 0 & 1 & 1 & 0 & Qin1012-02 \\
\hline 2 & 2 & 1 & 0 & 0 & 1 & 0 & 0 & 0 & 1 & 0 & Qin1012-03 \\
\hline 1 & 2 & 1 & 0 & 0 & 1 & 0 & 0 & 0 & 1 & 0 & Qin1012-04 \\
\hline 1 & 2 & 1 & 0 & 1 & 0 & 0 & 0 & 0 & 1 & 0 & LiEtal1012 \\
\hline 1 & 2 & 1 & 0 & 1 & 1 & 1 & 0 & 0 & 1 & 1 & LiEtal1314 \\
\hline 1 & 2 & 1 & 0 & 1 & 1 & 0 & 0 & 0 & 1 & 1 & Liu14 \\
\hline 2 & 1 & 1 & 0 & 0 & 1 & 0 & 0 & 0 & 1 & 1 & Luo14 \\
\hline
\end{tabular}

${ }^{\mathrm{a}}$ See Table 2 for variable definitions and values.

${ }^{\mathrm{b}}$ See Table 1 for basic information on the selected case studies. 


\section{Results}

The results of the QCA analysis of selected case studies are summarized in Table 4. Only minimized solutions are presented here for the identification of general patterns of conjoint configurations and for the ease of interpretation. There are three parsimonious combinations of factors associated respectively with the positive and negative impacts of migration on agricultural change. Migration-induced disintensification and decline of agricultural production tended to occur in those communities with limited land resources in Western China, or those with sufficient land but low economic development level and studied prior to the 2006 agricultural taxation reform. To a lesser extent, the combination of low agricultural dependency and some other factors (hilly/mountainous topography, low natural endowments, or low level of economic development) also contributed to this trend of agrarian restructuring. By contrast, moderate or high economic development context was particularly related to more positive migration-induced agricultural change. High dependence on agriculture consistently appeared in other solutions associated with constructive migration effects on agriculture, which also included Central China, moderate/high quantity of land resources, and the post-agricultural tax abolition study period.

The current literature on rural migration and agriculture in China and other developing countries concentrates on the micro- and macro-level analyses. Consequently, the contextual effects of local or community socioeconomic and environmental characteristics on migrationrelated agricultural transformation remain understudied. The patterns of conjunctural configurations found through our systematic review and meta-analysis can contribute to a better understanding of the diverse pathways of migration impacts on agriculture in rural China. The QCA analysis revealed differentiable but largely overlapping influences of geographical regions 
and economic development settings on the migration-agriculture relationships. Labor outmigration tended to support or supplement agricultural production in more affluent central and east coastal regions, while the opposite generally held true in less developed Western China. Similarly, agricultural dependence and time of study were associated with different trends in migration-related agricultural change in a rather consistent fashion. High dependence on agriculture and the post-agricultural tax abolition period usually corresponded to more positive effects of labor migration on local agricultural production.

\section{Table 4}

Results of the qualitative comparative analysis of migration impacts on agriculture

\begin{tabular}{|c|c|c|}
\hline Minimized Solution $^{\mathrm{a}}$ & Consistency $^{b}$ & Coverage $^{b}$ \\
\hline \multicolumn{3}{|l|}{ Negative migration impacts on agriculture ${ }^{c}$} \\
\hline Region $\{2\}$ LandResource $\{0\}$ & 1.00 & 0.45 \\
\hline LandResource $\{1\}$ EconDevelopment $\{0\}$ StudyTime $\{0\}$ & 1.00 & 0.36 \\
\hline \multicolumn{3}{|l|}{ AgriDependence $\{0\}$ Mountainous $\{1\}$ or } \\
\hline AgriDependence $\{0\}$ EconDevelopment $\{0\}$ & 1.00 & 0.27 \\
\hline Aggregate solution & 1.00 & 1.00 \\
\hline \multicolumn{3}{|l|}{ Positive migration impacts on agriculture ${ }^{c}$} \\
\hline EconDevelopment $\{1\}$ & 1.00 & 0.56 \\
\hline AgriDependence $\{1\}$ LandResource $\{1\}$ StudyTime $\{1\}$ & 1.00 & 0.22 \\
\hline \multicolumn{3}{|l|}{ AgriDependence $\{1\}$ Region $\{1\}$ LandResource $\{0\}$ or } \\
\hline Aggregate solution & 1.00 & 1.00 \\
\hline \multicolumn{3}{|c|}{$\begin{array}{l}{ }^{a} \text { Combinations of variables that exist logically but were missing in the dataset (logical remainders) were included in } \\
\text { the configuration reduction process. } \\
{ }^{b} \text { Consistency measures the proportion of cases with a given combination of factors that display a specific condition. } \\
\text { Coverage reflects the proportion of the instances of a condition covered by a given configuration. Only those } \\
\text { solutions with a coverage above the cutoff of } 0.20 \text { were included here. } \\
{ }^{c} \text { MVQCA uses the notation } X\{S\} \text { in which } X \text { refers to a variable in the dataset and } S \text { represents a value (or multiple } \\
\text { values) of } X \text {. See Table } 2 \text { for variable definitions and values. }\end{array}$} \\
\hline
\end{tabular}


The results also suggest that the effects of local land resource availability on the agricultural consequences of rural out-migration is contingent on several other contextual factors including geographical region, economic development, agricultural dependency, and the time of study. In conjunction with specific values of these variables, the scarcity or sufficiency of local land resources was related to both agricultural change outcomes. Moreover, the magnitude of labor migration and local non-farm work opportunities were not included in any of the minimized QCA solutions. This reflects the fact that these two factors were not systematically associated with particular trends of migration impacts on agriculture.

\section{Discussion}

There is no clear, singular conclusion emerging from the literature on China's ruralurban migration with regard to the impacts of out-migration on origin-area agriculture. The lack of authoritative evidence is in part due to the complexity of the issue and in part due to the difficulty of conducting a large-scale study encompassing multiple geographical regions, various agricultural resource conditions, and different levels of economic development. Because of this challenge, a major strategy of past research on the topic was to rely on the method of case studies. The practice is understandable because to effectively assess the effects of migration on agricultural efficacy, the specific economic and environmental contexts of different study areas must be taken into account. However, it is not clear whether we can draw out common patterns of the migration-agriculture relationships from this diverse body of studies.

Our research reported in this paper sets out to fill in this gap in the extant literature. Previous case studies became the raw data in our meta-analysis. By coding the socioeconomic and environmental contexts of the research sites in the selected studies as well as their findings 
and conclusions and by using QCA as our analytical method, we were able to cull the primary elements from those case studies and look at the big picture. That is, through our analysis, we have found some general patterns for describing the agricultural consequences of out-migration in the areas of origin.

A common view in environment and development research is that rural out-migration naturally leads to agricultural land abandonment and subsequent forest recovery (Rudel et al., 2005). The study shows the relationships between out-migration and agricultural change in a country as economically and biophysically diverse as China is more complicated than this "forest transition" perspective would suggest. Indeed, one can view China's rural-urban migration as both an outcome of the country's economic growth (and its agricultural market reform) and an impetus for more development (Liao and Qin, 2012). This further development may take the form of booming urban economies and of improving rural agricultural production. Our QCAbased meta-analysis found support for the latter, conditional upon the specific conjunctural configuration of a study site's economic development level or geographical locality, its land resources and dependence on agriculture, and whether the period under investigation was postagricultural tax abolition. This conclusion is particularly true for places in China's central and eastern regions. Our analysis suggested that when these conditions were lacking, the impact of out-migration on agriculture tended to be negative. Identifying such contextual patterns of migration impacts on agriculture would not have been possible without the meta-analysis in our study.

Community-level social, economic and biophysical features hold an important role in structuring the linkages between population dynamics and other rural restructuring processes (see Fig. 1). The moderating effects of community context on social and environmental changes 
have attracted increasing research attention in rural and natural resource social sciences.

Researchers have proposed a range of analytical techniques to capture community contextual influences, including rich narrative description, the construction of contextual variables using quantitative tools (e.g., geographic information systems and social network analysis), statistical analysis involving community-level variables and/or multi-level modeling, and the formulation of composite community indices and/or community typologies (Luke, 2005; Qin and Flint, 2012). Although often considered as a unconventional method, QCA is gaining currency in comparative social research (Liao, 2014) while its application has also been expanded to the examination of noncausal associations in forest policy research (Hellstrőm, 1998) and the meta-analysis of case studies of regional or global environmental change (Rudel, 2008). This study demonstrates that QCA can also serve as a useful tool for analyzing the community context shaping rural restructuring, and for informing evidence-based rural development planning and policy making.

\section{Concluding remarks}

To the best of our knowledge, this study presents the first systematic review and analysis of the impacts of labor out-migration on agricultural change in the rural social science literature. Applying QCA to an aggregate set of previously published case studies, we were able to gain a more complete understanding of this issue across multiple regions in China. Given the unique features in migration and rural restructuring dynamics across different countries, it should be meaningful to replicate this research design in other developing country settings or on an international scale. Increased knowledge about the migration-agriculture linkages can also enhance our conceptual understanding of the mediating role of agricultural practices in the outmigration impacts on the rural environment in the developing world (Qin and Flint 2012b). 
Additionally, while this analysis suggested general patterns of local contextual effects on the agricultural change resulting from labor out-migration in rural China, these factors can be readily included in large-scale household survey research to further evaluate their roles in adjusting the migration-agriculture nexus. Finally, the focus on local agricultural change in our meta-analysis is worth a special note. Both negative and positive migration impacts on agricultural production in migrant sending communities can be considered as parts of broader rural restructuring processes at the regional and national scales. Community characteristics limiting more constructive consequences of out-migration and remittances for agriculture in rural origin areas, such as unfavorable economic and environmental conditions, are often the factors resulting in substantial labor out-migration in the first place (Durand and Massey, 1992; Jokisch, 2002; Taylor, 1999; Zhang, 2010). Therefore, migration-induced withdrawal from agriculture in some rural communities may actually contribute to the improvement of regional or national agricultural structure. A more integrative approach combining micro, meso, and macro levels of analysis is needed in future research to provide a holistic view of the interactions between labor migration and transforming agricultural landscape in China and other developing countries. 


\section{References}

Bai, N., 2001. The effect of labor migration on agriculture: an empirical study. In: West, L., Zhao, Y. (Eds.) Rural Labor Flows in China. Berkeley Institute of East Asian Studies, Berkeley, CA, pp. 129-147.

Bernstein, H., 2015. Some reflections on agrarian change in China. Journal of Agrarian Change $15,454-477$.

Black, R., 1993. Migration, return, and agricultural development in the Serra Do Alvao, Northern Portugal. Economic Development and Cultural Change 41, 563-585.

Carney. D. (Ed.), 1998. Sustainable Rural Livelihoods: What Contribution Can We Make? London, UK, Department for International Development.

Carr, D., 2009. Population and deforestation: why rural migration matters. Progress in Human Geography 33, 355-378.

Chen, Z., Huffman, W. E., Rozelle, S., 2009. Farm technology and technical efficiency: evidence from four regions in China. China Economic Review 20, 153-161.

Collins, J., 1988. Unseasonal Migrations: The Effects of Rural Labor Scarcity in Peru. Princeton, NJ, Princeton University Press.

Croll, E. J., Huang, P., 1997. Migration for and against agriculture in eight Chinese villages. The China Quarterly 149, 128-146.

Cronqvist, L., 2011. Tosmana: Tool for Small-N Analysis [Computer Programme] Version 1.3.2.0. Trier: University of Trier.

Davin, D., 1999. Internal Migration in Contemporary China. Great Britain Antony Rowe Ltd. de Brauw, A., Rozelle, S., 2008. Migration and household investment in rural China. China Economic Review 19, 320-335. 
de Haan, A., 1999. Livelihoods and poverty: the role of migration. Journal of Development Studies 36, 1-47.

de Haas, H., 2006. Migration, remittances and regional development in Southern Morocco. Geoforum 37, 565-580.

Durand, J., Massey, D.S., 1992. Mexican migration to the United States: a critical review. Latin American Research Review 27, 3-42.

Durand, J., Parrado, E., Massey, D., 1996. Migradollars and development: a reconsideration of the Mexican case. International Migration Review 30, 423-444.

Gray, C. L., 2009. Rural out-migration and smallholder agriculture in the southern Ecuadorian Andes. Population and Environment 30, 193-217.

Gray, C.L., Bilsborrow, R.E., 2014. Consequences of out-migration for land use in rural Ecuador. Land Use Policy 36, 182-191.

Ellis, F., 2000. Rural Livelihoods and Diversity in Developing Countries. Oxford: Oxford University Press.

Garcia-Barrios, R., Garcia-Barrios, L., 1990. Environmental and technological degradation in peasant agriculture: a consequence of development in Mexico. World Development $18,1569-1585$.

Gilles, J.L., Thomas, J.L., Valdivia, C., Yucra, E.S., 2013. Laggards or leaders: Conservers of traditional agricultural knowledge in Bolivia. Rural Sociology 78, 51-74.

Hellstrőm, E., 1998. Qualitative comparative analysis: a useful tool for research into forest policy and forestry conflicts. Forest Science 44, 254-265.

Hoggart, K., Paniagua, A., 2001. What rural restructuring? Journal of Rural Studies 17, 41-62. 
Hull, J., 2007. Migration, remittances, and monetization of farm labor in subsistence sending areas. Asian and Pacific Migration Journal 16, 451-484.

Jokisch, B., 2002. Migration and agricultural change: the case of smallholder agriculture in highland Ecuador. Human Ecology 30, 523-550.

Li, C., Li, S., Feldman, M. W., Tai, X., 2010. The Influence of Labor Out-migration on Rural Households' Livelihood Capital in Rural Mountain Area of Western China. Population and Economics 31, 20-26 (in Chinese).

Li, C., Li, S., Feldman, M.W., Daily, G.C., Li, J., 2012. Does out-migration reshape rural households' livelihood capitals in the source communities? Recent evidence from Western China. Asian and Pacific Migration Journal 21, 1-30.

Li, Q., 2001. Rural labor migrants and remittances in China. Sociological Research 16, $64-76$ (in Chinese).

Li, Y., 2006. The Impact of Rural Migration on Village Development: A Comparative Study in Three Chinese Villages, Doctoral Dissertation, Baltimore, Maryland, Johns Hopkins University.

Li, L., Wang, C., Segarra, E., Nan, Z., 2013. Migration, remittances, and agricultural productivity in small farming systems in Northwest China. China Agricultural Economic Review 5, 5-23.

Li, L., Tonts, M., 2014. The impacts of temporary labour migration on farming systems of the Loess Plateau, Gansu Province, China. Population, Space and Place 20, 316-332.

Liao, T. F., 2014. Editor's introduction. Sociological Methodology. 44, ix-xi. 
Liao, T. F., Qin, H., 2012. Population growth, available resources, and quality of life: China's post-reform economic development. Chinese Journal of Population, Resources and Environment 10:67-77.

Liu, J., 2014. The impacts of rural labor migration on agricultural production in Pengshui County. Journal of Anhui Agricultural Science. 42, 9129-9131 (in Chinese).

Long, H., 2014. Land consolidation: an indispensable way of spatial restructuring in rural China. Journal of Geographical Sciences 24, 211-225.

Long, H., Woods, M., 2011. Rural restructuring under globalization in eastern coastal China: what can be learned from Wales? Journal of Rural and Community Development 6, 7094.

Long, H., Zou, J., Pykett, J., Li, Y., 2011. Analysis of rural transformation development in China since the turn of the new millennium. Applied Geography 31, 1094-1105.

Lovering, J., 1989. The restructuring debate. In: Peet, R. (Ed.), New Models in Geography, Vol. 1. London, Unwin Hyman, pp. 198-223.

Luke, D. A., 2005. Getting the big picture in community science: methods that capture context. American Journal of Community Psychology 35, 185-200.

Luo, G., 2014. The impacts of rural labor migration on agricultural production in Yudu County, Jiangxi Province. Rural South 30, 23-28 (in Chinese).

Luo, T., Escalante, C., 2015. Would more extensive out-migration of rural farmers expedite farm mechanization? Evidence from a changing Chinese agricultural sector. 2015 Annual Meeting, January 31-February 3, 2015, Atlanta, Georgia, Southern Agricultural Economics Association. 
McCarthy, N., Carletto, G., Davis, B., Maltsoglou, I., 2006. Assessing the impact of massive out migration on agriculture. Working Paper No. 06-14. Agricultural and Development Economics Division, Food and Agriculture Organization of the United Nations,

Mazambani, D., 1990. Labor Migration Impacts on Communal Land Agriculture: Case Studies from Manicaland Province, Zimbabwe, Doctoral Dissertation, Worcester, MA, Clark University.

Mendola, M., 2008. Migration and technological change in rural households: complements or substitutes? Journal of Development Economics 85, 150-175.

Miluka, J., Carletto, G., Davis, B., Zezza, A., 2009. The vanishing farms? The impact of international migration on Albanian family farming. The Journal of Development Studies 46, $140-161$.

Murphy, R., 2002. How Migrant Labor is Changing Rural China. Cambridge, Cambridge University Press. .

Nelson, P. B., 2001. Rural restructuring in the American West: land use, family and class discourses. Journal of Rural Studies 17, 395-407.

Oberai, A. S., Bilsborrow, E., 1984. Theoretical perspectives on migration. In: Bilsborrow, R. E., Oberai, A. S., Standing, G. (Eds.), Migration Surveys in Low-income Countries: Guidelines for Survey and Questionnaire Design, London and Sydney, Croom Helm, pp. 14-30.

Qin, H., 2009. The Impacts of Rural-to-Urban Labor Migration on the Rural Environment in Chongqing Municipality, Southwest China: Mediating Roles of Rural Household Livelihoods and Community Development, Doctoral Dissertation, University of Illinois 
at Urbana-Champaign, Urbana, Illinois.

https://www.ideals.illinois.edu/handle/2142/14577.

Qin, H., 2010. Rural-to-urban labor migration, household livelihoods, and the rural environment in Chongqing Municipality, Southwest China. Human Ecology 38, 675-690.

Qin, H., Flint, C.G., 2012a. The impacts of rural labor out-migration on community interaction and implications for rural community-based environmental conservation in Southwest China. Human Organization 71, 135-148.

Qin, H., Flint, C.G., 2012b. Integrating rural livelihoods and community interaction into migration and environment research: a conceptual framework of rural out-migration and the environment in developing countries. Society and Natural Resources 25, 1056-1065.

Qin, H., Grigsby, M.E., 2016. A "meta-study" of meta-analytical approaches to the human dimensions of environmental change. Human Ecology Review 22 (in press). http://hdl.handle.net/1885/101190.

Ragin, C. C., 2000. Fuzzy Set Social Science. Chicago, University of Chicago Press.

Ragin, C. C., 2014. The Comparative Method: Moving beyond Qualitative and Quantitative Strategies. Oakland, CA, University of California Press.

Reichert, J., 1981. The migrant syndrome: seasonal U.S. wage labor and rural development in Central Mexico. Human Organization 40, 56-66.

Robinson, B. E., Holland, M. B., Naughton-Treves, L., 2014. Does secure land tenure save forests? A meta-analysis of the relationship between land tenure and tropical deforestation. Global Environmental Change 29, 281-293. 
Romero-Lankao, P., Qin, H., Dickinson, K., 2012. Urban vulnerability to temperature-related hazards: a meta-analysis and meta-knowledge approach. Global Environmental Change $22,670-683$.

Rozelle, S., Taylor, J. E., de Brauw, A., 1999. Migration, remittances, and agricultural productivity in China. The American Economic Review 89, 287-291.

Rudel, T. K., 2008. Meta-analyses of case studies: a method for studying regional and global environmental change. Global Environmental Change 18, 18-25.

Rudel, T. K., Coomes, O. T., Moran, E., Achard, F., Angelsen, A., Xu, J., Lambin, E., 2005. Forest transitions: towards a global understanding of land use change. Global Environmental Change 15, 23-31.

Schmook, B., Radel, C., 2008. International labor migration from a tropical development frontier: globalizing households and an incipient forest transition. Human Ecology 36, 891-908.

Scoones, I., 2009. Livelihoods perspectives and rural development. The Journal of Peasant Studies 36, 171-196.

Simelane, H. S., 1995. Labour migration and rural transformation in post-colonial Swaziland. Journal of Contemporary African Studies 13, 207-226.

Stark, O., 1980. On the role of urban-rural remittances in rural development. Journal of Development Studies 16, 369-374.

Stark, O., 1991. The Migration of the Labor, Cambridge, Massachusetts, Harvard University Press.

Taylor, J., 1999. The new economics of labour migration and the role of remittances in the migration process. International Migration 37, 63-88. 
Taylor, J., Rozelle, S., de Brauw, A., 2003. Migration and incomes in source communities: a new economics of migration perspective from China. Economic Development and Cultural Change 52, 75-101.

Vasco, C., 2011. The Impact of International Migration and Remittances on Agricultural Production Patterns, Labor Relationships and Entrepreneurship: The Case of Rural Ecuador. Kassel University Press.

Vink, M. P., van Vliet, O., 2009. Not quite crisp, not yet fuzzy? Assessing the potentials and pitfalls of multi-value QCA. Field Methods 21, 265-289.

Wei, Z., 2005. An empirical study on the effects of rural labor migration on land use in mountainous areas of Beijing. Master Thesis, Beijing, China Agricultural University (in Chinese).

Wilson, O.J., 1995. Rural restructuring and agriculture-rural economy linkages: a New Zealand study. Journal of Rural Studies 11, 417-431.

Woods, M., 2005. Rural Geography: Processes, Responses and Experiences in Rural Restructuring. London, Sage.

Woods, M., 2007. Engaging the global countryside: globalization, hybridity and the reconstitution of rural place. Progress in Human Geography 31, 485-507.

Xu, C., Wang, H. H., Shi, Q., 2012. Farmers' income and production responses to rural taxation reform in three regions in China. Journal of Agricultural Economics 63, 291-309.

Yang, J., Wang, H., Jin, S., Chen, K. Z., Riedinger, J., Chao, P., 2014. Migration, local off-farm employment, and agricultural production efficiency: evidence from China. IFPRI Discussion Paper 1338. Washington, D.C., International Food Policy Research Institute. 
Yue, B., Sonoda, T., 2014. Effects of household heads' wage work on farm technology level and technical efficiency in China. Journal of Chinese Economic Studies 11, 1-21.

Zhang, M., 2010. The impact of rural-urban migration: case study on the Loess Plateau of Central China. China Information 24, 169-189.

Zhang, Q. F., Oya, C., Ye, J., 2015. Bringing agriculture back in: The central place of agrarian change in rural China studies. Journal of Agrarian Change 15, 299-313.

Zimmerer, K. S., 1993. Soil erosion and labor shortages in the Andes with special reference to Bolivia, 1953-91: implications for “conservation-with-development”. World Development 21, 1659-1675. 